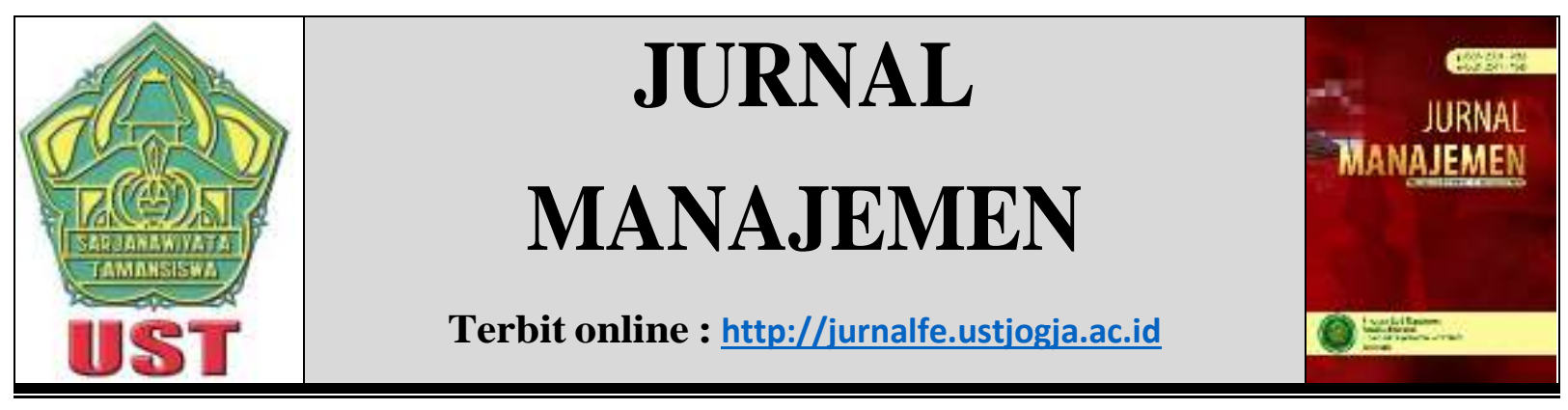

\title{
HUBUNGAN WORKPLACE RELATIONSHIP, CO-WORKER TRUST, JOB SATISFACTION, AFFECTIVE ORGANIZATION COMMITMENT, DAN INTENTION TO LEAVE
}

\author{
Daniel Joel Immanuel Kairupan
}

Program Studi Manajemen, STIE YKPN Yogyakarta

E-mail: danielkairupan@gmail.com

\begin{tabular}{|c|c|}
\hline Informasi Naskah & Abstrak \\
\hline $\begin{array}{l}\text { Diterima: } 9 \text { Maret } 2021 \\
\text { Revisi: } 27 \text { Mei } 2021 \\
\text { Terbit: } 18 \text { Juni } 2021\end{array}$ & $\begin{array}{l}\text { Human resources is a component that is very vital for a company. Human } \\
\text { resources with superior quality and competence are needed in daily } \\
\text { operational activities. But the problem that often arises in a company is }\end{array}$ \\
\hline $\begin{array}{l}\text { Keywords: Workplace } \\
\text { relationship, job } \\
\text { satisfaction, co-worker } \\
\text { trust, affective } \\
\text { organizational } \\
\text { commitment, intention } \\
\text { to leave }\end{array}$ & $\begin{array}{l}\text { the high intention of employees to leave the company for various reasons. } \\
\text { First, it is caused by the influence of a good working relationship } \\
\text { between employees and superiors or organizations. Second, there is trust } \\
\text { created by fellow colleagues. Third, organizational commitment to what } \\
\text { is done. Fourth, from the level of employee job satisfaction. Some of the } \\
\text { above are factors that cause employees to move companies. } \\
\text { This study aims to examine the relationship between workplace } \\
\text { relationships, co-worker trust, job satisfaction, affective organizational } \\
\text { commitment and intention to leave. Research data collection was carried } \\
\text { out using a questionnaire-based survey method. Respondents of this } \\
\text { study were } 150 \text { employees in the Special Region of Yogyakarta with the } \\
\text { criteria of having worked for at least one year and having direct } \\
\text { superiors who were directly responsible to them. } \\
\text { Hypothesis testing is done using SEM PLS. The results of correlation } \\
\text { between constructs are measured by looking at the path coefficients and } \\
\text { their level of significance which are then compared with the research } \\
\text { hypothesis. }\end{array}$ \\
\hline
\end{tabular}

\section{PENDAHULUAN}

Tantangan perusahaan dalam revolusi industri 4.0 menjadi sebuah isu yang sedang banyak dibahas. Hal ini juga sangat berpengaruh pada perubahan dan aktivitas sumber daya. Untuk melakukan kegiatan operasionalnya, setiap perusahaan membutuhkan sumber daya manusia yang memiliki kualitas dan kompetensi yang unggul. Konsep komitmen organisasi terpusat pada strategi sumber daya manusia yang terhubung kebijakan dan hasil. Perusahaan dengan sengaja menciptakan sebuah kondisi kerja yang nyaman agar karyawan dapat bekerja dengan baik dan mampu memperoleh keuntungan perusahaan. Namun permasalahan yang sering terjadi dalam sebuah perusahaan adalah tingginya niat karyawan untuk keluar dari perusahaan dengan beragam penyebab.

Alasan pertama yang sering terjadi adalah dikarenakan adanya konflik yang dikarenakan munculnya perbedaan pemikiran atau banyaknya keanekaragaman baik yang disebabkan karena usia, 
gender, suku, ras, atau masih banyak lagi (Hackman, 2009). Konflik tersebut jika tidak diatasi dengan baik, dapat menyebabkan kerugian bagi perusahaan. Alasan kedua seseorang yang mendasari seorang karyawan pada akhirnya memilih bertahan atau tidak dalam sebuah perusahaan adalah kepercayaan dalam sebuah hubungan kerjasama dapat terwujud dari adanya intensitas komunikasi yang baik antar pekerja.

Heathfield (2015) berpendapat terdapat hubungan positif antara nilai keterlibatan kerja karyawan dengan penilaian atasan terhadap kinerja mereka, dan sangat mungkin dengan mendorong keterlibatan kerja yang lebih besar akan secara positif memengaruhi perilaku kerja, khususnya perilaku individually directed citizenship. Ketiga adalah adanya tingkat kepuasan kerja. Karyawan dapat menggunakan kemampuan atau keahlian dalam menyelesaikan pekerjaan, mereka akan merasa sangat dihargai dan mampu menumbuhkan rasa kepercayaan diri mereka. Heatfield (2015) juga menambahkan ada faktor lain yang menyebabkan seorang karyawan memilih tidak keluar dari perusahaannya, yaitu adanya hubungan baik sesama karyawan yang disebabkan munculnya kepercayaan baik antar karyawan ataupun dari manajer ke karyawan. Ketika manajer serta rekan kerja bersedia untuk membantu mereka bekerja, ada sebuah kepuasan.

Dalam penelitiannya, Rotenberry dan Moberg (2007) menyatakan bahwa terdapat hubungan positif antara nilai keterlibatan kerja karyawan dengan penilaian atasan terhadap kinerja mereka, dan sangat mungkin dengan mendorong keterlibatan kerja yang lebih besar akan secara positif memengaruhi perilaku kerja, khususnya perilaku individually directed citizenship.

Rigoni (2016) menjelaskan bahwa perusahaan perlu untuk berkolaborasi, bekerja sama dengan pihak karyawan untuk mendapatkan masukan mengenai hal-hal apa yang harus dilakukan. Dengan pendekatan ini, diharapkan pekerja akan merasa bahwa perusahaan sangat membutuhkan mereka dan bagi pihak perusahaan dapat mencapai tujuan mereka, yaitu pencapaian kinerja yang maksimal dengan salah satu indikatornya adalah memperoleh keuntungan yang optimal. Melihat hal inilah, banyak perusahaan yang melibatkan karyawan dalam setiap aktivitas yang mereka lakukan. Tujuannya adalah untuk menciptakan kepercayaan karyawan terhadap pihak perusahaan (Tan dan Lim, 2010). Sebagai contoh adalah Pixar Animations Studios yang merupakan sebuah studio animasi Amerika Serikat berhasil mengembangkan usahanya dengan melibatkan semua karyawannya dalam setiap aktivitasnya. Pixar menilai bahwa sebuah keberhasilan organisasi juga dipengaruhi dengan ideide yang muncul dari para karyawan yang bertalenta. Selain itu perlu adanya sebuah keterikatan antara karyawan satu dengan yang lainnya dalam hal saling memberi dukungan (Florida dan Goodnight, 2005).

Perusahaan harus mampu melibatkan seluruh karyawannya untuk mampu bekerja sama guna mencapai tujuan perusahaan. Tentu saja semua ini memerlukan strategi yang tepat dan akurat. Kemampuan perusahaan inilah yang kemudian mendasari bahwa perlu adanya affective organizational commitment. Terdapat dua proses untuk membentuk komitmen, pertama tindakan manajemen dalam menerapkan berbagai kebijakan yang akan menghasilkan sumber daya manusia yang mencakup kebijakan strategis dan komitmen organisasi. Kedua, dengan sumber daya manusia akan menghasilkan kinerja yang tinggi, kapasitas pemecahan masalah, dan efektifitas pada biaya.

Kepemimpinan, budaya, dan tindakan strategi akan berpengaruh pada komitmen organisasi. Kebijakan manajemen sumber daya manusia pada nantinya akan mempengaruhi terbentuknya komitmen yang dapat terlihat dari karyawan terhadap organisasi. Komitmen organisasi juga dapat dikonsepkan menjadi beberapa hal. Porter dalam (Eslami dan Gharakhani, 2012) mengungkapkan mengenai kemampuan yang dimiliki oleh masing-masing individu serta keterlibatannya dalam sebuah organisasi tertentu.

Kepercayaan dalam sebuah hubungan kerjasama dapat terwujud dari adanya intensitas komunikasi yang baik antar pekerja. Porter et al, dalam McAllister (1995) menjelaskan bahwa sebuah kepercayaan dianggap baik dalam sebuah perusahaan. Inilah alasan kedua seseorang yang mendasari seorang karyawan pada akhirnya memilih bertahan atau tidak dalam sebuah perusahaan.

Kepuasan kerja karyawan terdiri dari beberapa komponen yang terdiri dari lingkungan ekonomi dan politik, kekuasaan, lingkungan organisasi, lingkungan pekerjaan, demografi, 
kepribadian personal, kemampuan, kepribadian situasional, tingkat persepsi karyawan, ciri-ciri kepribadian sementara, konsep antar hubungan, tanggapan perorangan atau karyawan, tanggapan perusahaan, dan tanggapan sosial (Seashore dan Taber, 1975). Kepuasan kerja dipengaruhi dari dua nilai, yaitu internal dan eksternal. Nilai internal membahas tentang pengakuan statusnya dalam perusahaan, kesempatan untuk mengembangkan kemampuan dirinya, dan status kepegawaiannya. Ekstrinsik memiliki nilai untuk membahas tentang aspek-aspek yang berwujud. Misalnya gaji, bonus, atau pembagian saham (Alam dan Mohhamad, 2010).

Dari penjelasan diatas dapat dilihat bahwa seorang karyawan akan merasa nyaman berada didalam sebuah perusahaan jika mendapatkan apa yang mereka perlukan. Kepercayaan dapat muncul dari interaksi karyawan yang dapat mempangaruhi orang lain untuk melakukan apa yang diinginkan. Kepercayaan ini dapat membentuk kepercayaan positif dalam organisasi dan ikut mempengaruhi apakah karyawan tersebut ingin tetap berada di dalam perusahaan tersebut atau tidak (Balkan, et. al., 2014). Purnadi (2019) menjelaskan bahwa pada saat ini tingkat keinginan karyawan untuk tetap tinggal atau keluar dari pekerjaannya juga dipengaruhi oleh kepuasan kerja, komitmen organisasi. Terutama jika melihat bahwa cukup banyak

Melihat banyaknya perusahaan yang saat ini menghadapi persoalan tingginya niat untuk berpindah (intention to leave) sehingga peneliti merumuskan masalahnya sebagai berikut apakah workplace relationship, job satisfaction, affective organizational commitment, co-worker trust berpengaruh pada intention to leave.

\section{KAJIAN PUSTAKA DAN HIPOTESIS \\ Co-Worker Trust}

Co-Worker Trust atau tingkat kepercayaan rekan kerja merupakan sebuah bentuk kepedulian sesama rekan kerja yang saling percaya dan saling mempengaruhi, yang kemudian akan mengarah pada hasil organisasi yang berfokus pada komitmen dan prestasi (Purnadi, 2019). Kepercayaan terbagi atas dua tipe, yaitu calculus-based trust (CBT) dan identification-based trust (IBT). Dalam CBT kepercayaan lebih berhubungan pada tempat kerja, sehingga didalamnya terdapat pemberian penghargaan dan sistem hukuman. Sedangkan untuk IBT lebih berhubungan secara personal. Sehingga kepercayaan atau ketidakpercayaan memiliki dua konsep yang berbeda. Dalam kepercayaan, salah satu pihak harus memiliki harapan positif mengenai tindakan yang lain sehingga dengan hal tersebut akan memunculkan rasa keyakinan pada orang lain. Namun, ketidakpercayaan akan memunculkan rasa ketakutan pada orang lain (Balkan, et. al, 2014). Mereka juga menambahkan bahwa dalam dunia kerja cenderung sebagai bentuk CBT, namun juga memiliki kemungkinan mengembangkan IBT dari waktu ke waktu. Kepercayaan terhadap rekan kerja juga sangat berpengaruh terhadap berbagi pengetahuan. Menurut Von Krogh (dalam Kim dan Lee, 2006) kepercayaan dan keterbukaan dalam budaya organisasi mendorong karyawan untuk saling berbagi pengetahuan dan perilaku yang saling percaya tersebut dapat meningkatkan kecepatan komunikasi dengan memberikan wewenang pada rekan kerja dalam berbagi masalah dan pengetahuan pribadi dengan lebih leluasa. Kepercayaan seperti ini yang kemudian disebut sebagai kepercayaan interpersonal. Kepercayaan interpersonal dapat didefinisikan sebagai sebuah persepsi yang harus kita miliki bahwa orang lain tidak akan melakukan apapun yang dapat merugikan kita (Williams, 2015).

\section{Job Satisfaction}

Penelitian dan konsep mengenai kepuasan kerja telah dimulai sebelum tahun 1950 an. Dimulai dari Profesor Hoppock pada tahun 1935 yang merupakan seorang profesor pendidikan psikologi dari New York University, menjelaskan bahwa kepuasan kerja adalah kombinasi psikologis, fisiologis, dan lingkungan yang menyebabkan seseorang untuk dapat berkata jujur akan posisi dan keadaan pekerjaannya. Kepuasan kerja meliputi respon psikologis multidimensional terhadap sebuah pekerjaan, termasuk didalamnya adalah respon evaluatif, afektif atau ikatan emosional dan komponen perilaku karyawan tersebut. Kepuasan kerja merupakan keadaan emosional yang positif dari seseorang yang ditimbulkan dari penghargaan atas sesuatu pekerjaan yang telah dilakukannya. 
Kepuasan kerja secara umum merupakan hasil dari banyaknya sikap yang berasal dari tiga faktor, yaitu faktor spesifikasi pekerjaan, karakteristik individual, dan hubungan kelompok di luar pekerjaan (Mishra, 2013).

Kepuasan kerja biasanya diukur dengan menggunakan metode penelitian ilmiah umum seperti kuesioner. Misalnya dengan kuesioner kepuasan Minnesota dan indeks deskripsi pekerjaan (Aziri, 2011). Kedua cara tersebut akan melihat tingkat kepuasan karyawan terhadap pekerjaannya baik secara individual atau kelompok. Aziri juga menjelaskan bahwa kepuasan kerja juga berpengaruh pada banyak aspek kehidupan organisasi. Termasuk pada produktivitas karyawan, loyalitas, dan ketidakhadiran karyawan.

Workplace RelationshipDalam konteks ini, hubungan kerja mengacu pada perawatan dan pertimbangan bahwa setiap karyawan diterima dengan baik oleh atasan atau rekan kerja (Lather dan Singh, 2015). Pada umumnya, sebuah hubungan kerja yang baik juga didasari dengan ada tidaknya konflik antar individu. Hayes (2008) mengemukakan bahwa dampak dari adanya konflik dalam sebuah hubungan kerja adalah munculnya demotivasi dalam bekerja. Meskipun setiap hari karyawan tidak selalu mengalami konflik tetapi hal ini sangat mengganggu mereka untuk dapat mengembangkan potensi mereka. Ia menambahkan, bahwa setiap karyawan perlu bertanggungjawab terciptanya hubungan kerja yang baik.

Sementara itu, Green et. al (2015) menjelaskan bahwa manajer atau supervisor harus bertanggung jawab terhadap terciptanya hubungan kerja yang kondusif. Hubungan kerja yang baik dapat membantu terciptanya peluang bagi karyawan untuk dapat mengembangkan kemampuannya serta memperoleh dukungan emosional dari rekan kerja lainnya (Colbert et. al, 2016). Terciptanya hubungan kerja yang baik juga didasari oleh adanya hubungan yang baik antara atasan bawahan ataupun sesama rekan kerja dan juga dari organisasi (Cross, 1973).

\section{Affective Organizational Commitment}

Komitmen mengarah pada loyalitas. Biasanya lebih mengarah pada seorang karyawan dengan perusahaan atau organisasi. Konsep komitmen organisasi terpusat pada strategi sumber daya manusia yang terhubung kebijakan dan hasil. Mowday et. al dalam Albdour dan Altarawneh (2014) mendefinisikan komitmen organisasi sebagai sebuah langkah untuk mengidentifikasi individu dengan cara ikut terlibat dalam organisasi tertentu yang ditdanai dengan adanya keyakinan yang kuat serta penerimaan tujuan dan nilai-nilai organisasi, kesediaan untuk mengerahkan usaha yang cukup atas nama organisasi dan keinginan yang kuat untuk mempertahankan keanggotaan organisasi tersebut.

Komitmen organisasi sering digunakan untuk menghubungkan antara individu dengan organisasi. Selain itu komitmen organisasi juga menekankan pada komitmen antara individu dan organisasi (Mathieu dan Zajac, 1990). Dalam hal ini, masing-masing individu akan terikat pada organisasi karena mereka telah menghabiskan waktunya dalam organisasi tersebut. Komitmen diidentifikasikan melalui ketiga pendekatan, yaitu affective, continuance, dan normative commitment. Affective commitment adalah keterlibatan individu yang berdasarkan keterikatan emosi yang berdasarkan pada empat kategori, yaitu karakteristik personal, karakteristik struktural, karakteristik keterikatan pekerjaan, dan pengalaman kerja. Continuance commitment adalah perhitungan terkait besaran biaya yang terkait dengan meninggalkan organisasi. Normative commitment adalah keterikatan yang terjadi berdasarkan kesetiaan, penghargaan yang telah diberikan kepada individu sehingga mereka merasa bahwa sudah seharusnya mereka tetap dalam organisasi tersebut.

Affective commitment sering didefinisikan sebagai inti dari komitmen organisasi. Komitmen afektif lebih cenderung menyoroti tentang keterikatan emosi yang biasanya menyoroti tentang sikap karyawan untuk tetap bersedia berada di organisasi, kesediaan untuk mengikuti nilai-nilai perusahaan. Karyawan yang memiliki komitmen afektif akan memiliki ketertarikan yang sangat tinggi terhadap perusahaan. Komitmen afektif terbentuk dari adanya karakteristik personal masing-masing karyawan, komitmen perilaku karyawan dalam perusahaan serta pengalaman kerja karyawan tersebut (Albdour dan Altarawneh, 2014). 
Intention To Leave

Pergantian karyawan atau turnover karyawan telah menjadi sebuah isu penting di beberapa organisasi atau perusahaan. Rasio pergantian karyawan berpengaruh juga pada biaya perekrutan dan pelatihan karyawan baru yang harus dikeluarkan oleh pihak perusahaan serta juga berpengaruh pada penurunan hasil kinerja perusahaan (Basak et. al, 2013). Strategi untuk mengurangi pergantian karyawan merupakan tanggungjawab dari manajemen untuk mengambil kebijakan terhadap proses perekrutan, seleksi, pelantikan, pelatihan, perencanaan pekerjaan, dan pembayaran gaji. Pergantian karyawan yang sangat cepat merupakan bentuk seleksi yang tidak terlalu baik (Ongori, 2007). Ongori menjelaskan bahwa pergantian karyawan dapat diartikan sebagai sebuah perencanaan oleh karyawan untuk keluar dari pekerjaannya dan mencoba untuk memperoleh pekerjaan lainnya.

Dengan dasar penelitian terdahulu oleh Lather dan Singh (2015) yang meneliti mengenai dampak hubungan kerja dalam niat untuk berpindah, ditemukan ada hubungan yang positif dalam hubungan atasan-bawahan dengan keinginan berpindah. Karyawan yang dimaksud adalah karyawan yang langsung dibawah pengawasan pihak manajemen. Namun hasil tersebut tidak sesuai apabila karyawan tersebut tidak berada dalam pengawasan manajemen tersebut secara langsung. Mete dan Sokmen (2016), menegaskan bahwa rusaknya hubungan kerja dapat disebabkan dari adanya perilaku yang kurang menguntungkan dari rekan kerja lainnya. Berdasarkan penelitian mereka, menjelaskan bahwa tidak ada hubungan positif antara hubungan kerja atau workplace relationship dan niatan untuk berpindah. Dari penelitian tersebut maka dapat dikembangkan hipotesis 1 sebagai berikut:

\section{H1: Workplace Relationship berpengaruh positif terhadap niat untuk berpindah.}

Penelitian Mbah dan Ikemefuna (2012) yang meneliti mengenai kedua hubungan ini di Nigeria menyatakan bahwa kepuasan kerja memiliki pengaruh yang positif dengan niat untuk berpindah. Mereka menjelaskan bahwa kedua hubungan ini cukup erat. Ketika karyawan merasa puas akan pekerjaannya, keinginan untuk keluar pasti akan tidak ada. Issa et. al (2013) juga menegaskan bahwa kepuasan kerja berpengaruh terhadap niat untuk berpindah. Namun Issa membagi tingkat kepuasan menjadi beberapa kategori, diantaranya adalah kepuasan kerja, kepuasan akan gaji dan kepuasan akan atasan atau pimpinan. Begitupun dengan dengan Aziri (2011) juga menegaskan bahwa niat untuk keluar dapat dipengaruhi oleh adanya kepuasan akan pekerjaan. Misalnya dengan mendapatkan promosi, kenaikan gaji, atau memperoleh kepercayaan dalam melakukan pekerjaan mereka. Sehingga dengan ini dapat dikembangkan hipotesis 2 sebagai berikut:

H2: Kepuasan kerja atau job satisfaction berpengaruh positif terhadap niat untuk berpindah.

Komitmen organisasi merupakan salah satu hal yang mempengaruhi karyawan bertahan dalam sebuah perusahaan atau yang disebut intention to leave. Seperti yang telah dijelaskan sebelumnya, bahwa komitmen organisasi memiliki tiga aspek yaitu affective, continuance, dan normative. Yasmin dan Marzuki (2015) menjelaskan bahwa komitmen organisasi memiliki pengaruh cukup besar terhadap keinginan karyawan untuk tetap didalam organisasi atau tidak. Mereka menegaskan bahwa terdapat hubungan antara kedua faktor tersebut. Komitmen organisasi afektif termasuk membahas tentang keadilan di tempat kerja dan keadilan antar karyawan dalam satu perusahaan. Dari dugaan tersebut dapat dikembangkan hipotesis 3 sebagai berikut:

H3: Affective Organizational Commitment berpengaruh positif terhadap niat untuk berpindah.

Konsep komitmen organisasi afektif memiliki hubungan yang erat dengan kepercayaan dan dukungan rekan kerja (Tamer dan Dereli, 2014). Penelitian yang dilakukan oleh mereka, mengungkapkan fakta bahwa ada hubungan yang cukup erat antara kepercayaan dan komitmen organisasi. Secara intuitif akan terlihat bahwa kepercayaan memiliki signifikan dan dampak yang konsisten pada 
pengembangan komitmen organisasi. Cho dan Park (2011) mengemukakan bahwa kepercayaan antar rekan kerja juga berpengaruh positif pada kepuasan kerja dan komitmen.

\section{H4: Co-Worker Trust memiliki pengaruh positif terhadap pembentukan Affective Organizational Commitment.}

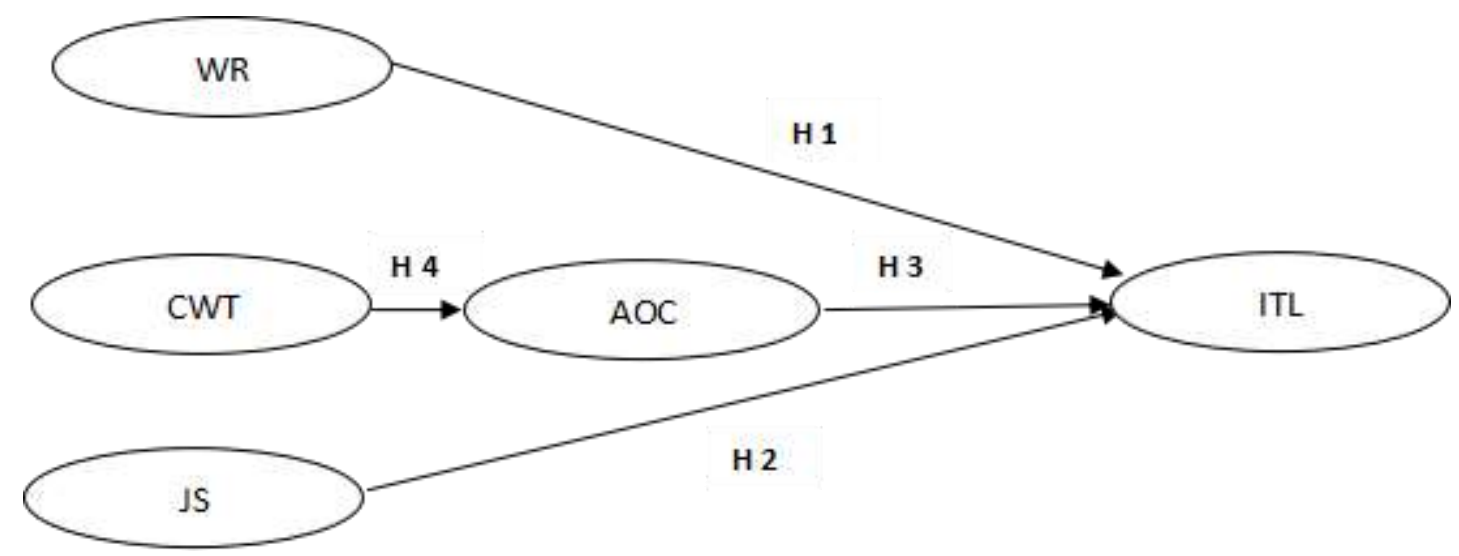

Gambar 1. Kerangka Penelitian

\section{METODE PENELITIAN}

Populasi yang menjadi subjek dalam penelitian ini adalah karyawan pada salah satu perusahaan perbankan di Daerah Istimewa Yogyakarta. Jumlah sampel tersebut didasarkan pada lima kali estimated parameter (Hair. et al., 1998). Sehingga jumlah sampel minimal adalah 5 x $20=100$. Namun dalam penelitian ini melibatkan 150 responden terpilih. Instrumen dalam penelitian ini mengadopsi instrumen penelitian yang telah dikembangkan oleh peneliti sebelumnya yang semua jawaban dari pertanyaan akan diukur dalam lima skor dengan menggunakan skala ordinal 5 poin Likert, mulai dari sangat setuju (poin 5) sampai sangat tidak setuju (poin 1).

Instrumen survei berisi dua bagian. Bagian 1 mencakup variabel pribadi dan demografi yang berbeda. Bagian ini akan mendapatkan informasi responden tentang jenis kelamin, usia, pendapatan, pendidikan, status. Bagian 2 termasuk variabel laten yang penting dalam penelitian ini. Variabelvariabel ini meliputi workplace relationship, job satisfaction, co-worker trust, affective commitment organizational, intention to leave.

Workplace Relationship atau hubungan kerja dalam penelitian ini mengacu pada interaksi antara individu dan rekan kerja mereka, supervisor mereka dan organisasi mereka. Variabel hubungan kerja ini diukur menggunakan instrumen berisi empat poin pertanyaan mengenai seberapa besar rating yang anda berikan terhadap sikap karyawan terhadap rekan kerja, atasan langsung, hubungan bawahan superior dan perusahaan atau organisasi secara keseluruhan (Cross, 1973).

Job Satisfaction lebih memilih menggunakan instrumen kuesioner yang dikembangkan oleh Rusbult dan Farrel (1983) yang juga digunakan oleh Sholihin dan Pike (2009). Instrumen ini dipilih karena dinilai lebih mudah dipahami dan karakteristik pertanyaan yang cukup konkrit dan berisi 6 item pertanyaan. Co-worker trust didefinisikan sebagai trust antar individu dengan rekan yang berada pada satu level fungsional atau satu divisi yang sama dalam organisasi. Variabel ini diukur menggunakan instrumen berisi 4 item pernyataan yang dikembangkan oleh Cook dan Wall (1980).

Affective commitment organizational diukur dengan menggunakan versi pendek $O C Q$ (organizational commitment questionnaire) milik Porter et al. (1974) dan juga digunakan oleh Mowday et al. (1979). Instrumen ini berisi 4 poin pernyataan. Sementara itu variabel intention to leave dalam penelitian ini didefinisikan sebagai rencana karyawan untuk berniat meninggalkan pekerjaan saat ini dan melihat seterusnya untuk mencari pekerjaan lain. Variabel ini diukur menggunakan instrumen yang diadaptasi dari Rizwan et al (2014).

Analisis induktif dengan menggunakan Partial Least Square (PLS) meliputi penelitian 
goodness of fit model (inner model), yang berfungsi ntuk mengetahui kecocokan suatu model yang digunakan dalam penelitian ini dengan menggunakan variabel workplace relationship, job satisfaction, affective organization commitment, co-worker trust dan intention to leave.

Hasil korelasi antar konstruk diukur dengan melihat path coefficients dan tingkat signifikansinya yang kemudian dibandingkan dengan hipotesis penelitian. Tingkat signifikansi yang dipakai dalam penelitian ini adalah sebesar 5\%. Dalam proses pengolahan hasil penelitian akan menggunakan teknik analisis data dengan menggunakan software WarpPLS 5.0. PLS digunakan dengan tujuan untuk memaksimalkan nilai varians yang dijelaskan oleh variabel prediktor terhadap variabel dependen melalui $R$-Square sebagai ukuran goodness-of-fit (Chin \& Newsted: 1999).

\section{HASIL DAN PEMBAHASAN}

Total sebanyak 150 kuesioner disebar oleh peneliti ke karyawan pada salah satu perusahaan perbankan di Daerah Istimewa Yogyakarta. Sebanyak 150 responden mengembalikan kuesioner (response rate sebesar 100\%). Karakteristik responden terdiri dari jenis kelamin, umur, tingkat pendidikan, masa kerja di perusahaan, dan jabatan. Berdasarkan informasi dari kuesioner, mayoritas responden berjenis kelamin laki-laki sebesar (68,57\%). Responden yang memiliki rentang usia terbesar dengan umur 30-40 tahun (34,64\%), dengan tingkat pendidikan terbanyak adalah S1 $(58,23 \%)$. Responden dengan masa kerja di perusahaan selama 2 hingga 5 tahun memiliki frekuensi paling besar (71 responden, 60\%), dan jabatan sebagai karyawan tetap memiliki jumlah paling besar (80 responden, $73,39 \%$ ).

Penggunaan WarpPLS 6.0 telah memberikan hasil perhitungan yang menunjukkan kriteria yang digunakan untuk menilai apakah model telah sesuai.

Tabel 1. Hasil Goodness of Fit Variabel dengan WarpPLS 6.0

\begin{tabular}{|c|c|}
\hline APC $=0,353, \mathrm{P}<0,001$ & Good if $\mathrm{P}<0,05$ \\
\hline $\mathrm{ARS}=0,577, \mathrm{P}=0,001$ & Good if $\mathrm{P}<0,05$ \\
\hline $\mathrm{AVIF}=1,294$ & Good if $\mathrm{P} \leq 5$ \\
\hline
\end{tabular}

Tabel 2. Tabel Reabilitas dan Validitas

\begin{tabular}{|c|c|c|c|c|c|c|c|c|c|c|}
\hline \multirow[t]{2}{*}{ No } & \multirow[t]{2}{*}{ Var } & \multirow[t]{2}{*}{ Indikator } & \multirow{2}{*}{$\begin{array}{c}\text { Faktor } \\
\text { Loading }\end{array}$} & \multirow{2}{*}{$\begin{array}{c}\mathrm{P} \\
\text { Value }\end{array}$} & \multicolumn{2}{|c|}{ Indikator } & \multirow[t]{2}{*}{ AVE } & \multirow[t]{2}{*}{$\mathrm{CR}$} & \multirow[t]{2}{*}{ Validitas } & \multirow[t]{2}{*}{ Reliabilitas } \\
\hline & & & & & Validitas & Reliabilitas & & & & \\
\hline \multirow[t]{4}{*}{1} & Work & Wr1 & 0.273 & 0.001 & valid & reliabel & 0.458 & 0.767 & Valid & Reliable \\
\hline & & Wr2 & 0.353 & $<0.001$ & valid & reliabel & & & & \\
\hline & & Wr3 & 0.433 & $<0.001$ & valid & reliabel & & & & \\
\hline & & $\mathrm{Wr} 4$ & 0.398 & $<0.001$ & valid & reliabel & & & & \\
\hline \multirow[t]{4}{*}{2} & Co-Work & Cwt1 & 0.404 & $<0.001$ & valid & reliabel & 0.448 & 0.760 & Valid & Reliable \\
\hline & & Cwt2 & 0.431 & $<0.001$ & valid & reliabel & & & & \\
\hline & & Cwt3 & 0.368 & $<0.001$ & valid & reliabel & & & & \\
\hline & & Cwt4 & 0.272 & 0.001 & valid & reliabel & & & & \\
\hline \multirow[t]{4}{*}{3} & JobSat & Jsat1 & 0.226 & 0.007 & valid & reliabel & 0.592 & 0.888 & Valid & Reliable \\
\hline & & Jsat2 & 0.531 & $<0.001$ & valid & reliabel & & & & \\
\hline & & Jsat3 & 0.238 & 0.005 & valid & reliabel & & & & \\
\hline & & Jsat4 & 0.155 & 0.047 & valid & reliabel & & & & \\
\hline
\end{tabular}


Kairupan / Jurnal Manajemen, Vol 11, No 1 (2021): $11-22$

\begin{tabular}{|c|c|c|c|c|c|c|c|c|c|c|}
\hline & & Jsat5 & 0.092 & 0.163 & valid & reliabel & & & & \\
\hline & & Jsat6 & 0 & 1.000 & valid & reliabel & & & & \\
\hline \multirow[t]{4}{*}{4} & Affective & Aoc1 & 0.276 & 0.001 & valid & reliabel & 0.422 & 0.736 & Valid & Reliable \\
\hline & & Aoc2 & 0.307 & $<0.001$ & valid & reliabel & & & & \\
\hline & & Aoc3 & 0.459 & $<0.001$ & valid & reliabel & & & & \\
\hline & & Aoc 4 & 0.459 & $<0.001$ & valid & reliabel & & & & \\
\hline \multirow[t]{4}{*}{5} & Intent & It11 & 0.404 & $<0.001$ & valid & reliabel & 0.448 & 0.760 & Valid & Reliable \\
\hline & & It12 & 0.431 & $<0.001$ & valid & reliabel & & & & \\
\hline & & It13 & 0.368 & $<0.001$ & valid & reliabel & & & & \\
\hline & & It14 & 0.272 & 0.001 & valid & reliabel & & & & \\
\hline
\end{tabular}

Berdasarkan hasil pengujian, dari tabel 1 diperoleh nilai Average Path Coefficient (APC) sebesar 0,353 dengan nilai $\mathrm{p}<0,001$, hal ini berarti nilai APC signifikan $(<0,05)$. Signifikan nilai APC dapat membuktikan bahwa variabel endogen dan eksogen memiliki hubungan sebab akibat baik secara langsung maupun tidak langsung. Nilai Average $R$-squared (ARS) diperoleh hasil 0,377 dengan nilai $\mathrm{p}=0,001$. Dengan hasil ini dapat disimpulkan bahwa nilai ARS signifikan karena nilai $\mathrm{p}<0,05$. Hasil tersebut membuktikan bahwa variabel independen dalam penelitian ini hanya mampu mempengaruhi $57,7 \%$ variabel dependen. Sedangkan 43,3\% dipengaruhi oleh variabel lainnya. Model penelitian pada penelitian ini tidak terjadi multikolinearitas karena nilai Average Variance Inflation Factor (AVIF) sebesar 1,294 yang nilainya $\leq 5$.

Pengujian hipotesis ini dimaksudkan untuk membuktikan kebenaran dugaan penelitian atau hipotesis. Hasil korelasi antar konstruk diukur dengan melihat path coefficients dan tingkat signifikansinya yang kemudian dibandingkan dengan hipotesis penelitian yang terdapat di bab dua. Tingkat signifikansi yang dipakai dalam penelitian ini adalah sebesar $5 \%$.

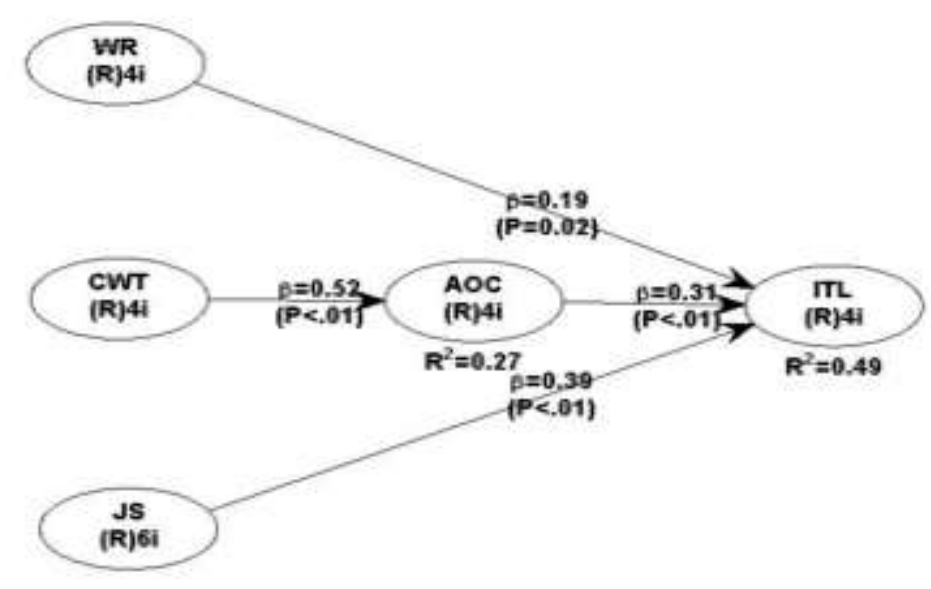

Gambar 2. Hasil pengujian variabel menggunakan WarpPLS 6.0

Hasil analisis menggunakan alat uji WarpPLS 6.0 yang ditunjukkan pada Gambar 5.2 yaitu hipotesis pertama dalam penelitian ini adalah pengaruh workplace relationship pada intention to leave karyawan. Hasil penelitian menunjukkan bahwa nilai $\mathrm{P}=0,02$ dengan nilai tingkat signifikansi 5\% hal tersebut menunjukkan bahwa variabel workplace relationship tidak berpengaruh terhadap intention to leave karyawan. Hipotesis kedua dalam penelitian ini adalah dalam penelitian ini adalah pengaruh job satisfaction terhadap intention to leave karyawan. Hasil penelitian menunjukkan bahwa 
nilai $\mathrm{P}<0,01$ dengan tingkat signifikansi 5\% hal tersebut menunjukkan bahwa variabel job satisfaction berpengaruh terhadap intention to leave karyawan.

Hipotesis ketiga dalam penelitian ini adalah pengaruh affection organizational commiment terhadap intention to leave. Hasil penelitian menunjukkan bahwa nilai $\mathrm{P}<0,01$ dengan tingkat signifikansi $5 \%$ hal tersebut menunjukkan bahwa variabel affection organizational commiment berpengaruh terhadap intention to leave karyawan. Dan hipotesis keempat adalah pengaruh co-worker trust terhadap affection organizational commiment. Hasil penelitian menunjukkan bahwa nilai $\mathrm{P}<$ 0,01 dengan tingkat signifikansi 5\% hal tersebut menunjukkan bahwa variabel pengaruh co-worker trust berpengaruh terhadap affection organizational commiment karyawan.

\section{Pembahasan}

Hipotesis satu menyatakan bahwa variabel workplace relationship berpengaruh positif pada intention to leave atau niat untuk berpindah karyawan. Dari hasil penelitian tidak terdapat hubungan yang positif antara kedua faktor tersebut. Hal ini didukung dengan penelitian yang dilakukan oleh Mete dan Sokmen (2016) yang menegaskan bahwa rusaknya hubungan kerja dapat disebabkan dari adanya perilaku yang kurang menguntungkan dari rekan kerja lainnya. Penelitian tersebut menjelaskan bahwa jenjang karir yang menjadi salah satu kunci utama akan adanya niatan karyawan untuk keluar. Sedangkan workplace relationship lebih cenderung tentang komunikasi antara pimpinan dan bawahannya dalam sebuah perusahaan.

Hipotesis kedua menyatakan bahwa variabel job satisfaction berpengaruh pada intention to leave karyawan. Mbah dan Ikemefuna (2012) menyatakan bahwa job satisfaction memiliki pengaruh positif terhadap intention to leave. Karyawan yang memiliki kepuasan kerja tinggi tidak akan tertarik untuk keluar dari pekerjaannya. Peningkatan kepuasan kerja karyawan akan mengakibatkan penurunan keinginan karyawan untuk keluar dari perusahaan. Job satisfaction juga memiliki pengaruh positif terhadap keinginan untuk keluar. Kepuasan kerja yang disebabkan oleh adanya komunikasi yang baik dengan rekan kerja memiliki pengaruh yang lebih besar dibandingkan kepuasan kerja yang disebabkan oleh adanya gaji ataupun penghargaan yang lebih bersifat ekstrinsik (Mahdi et. al, 2012).

Hipotesis ketiga menyatakan bahwa affection organizational commiment memiliki pengaruh yang signifikan terhadap intention to leave. Hal tersebut didukung dengan penelitian yang dilakukan oleh Yasmin dan Mazuki (2015) bahwa affection organizational commiment memiliki pengaruh signifikan terhadap intention to leave. Mereka juga menyatakan bahwa penekanan terhadap komitmen organisasi karyawan adalah cara yang efektif untuk mempertahankan tingkat karyawan untuk keluar dari perusahaan. Sedangkan hipotesis ketiga menyatakan bahwa co-worker trust memiliki pengaruh signifikan terhadap affection organizational commiment. Jafri (2016) menyatakan bahwa dukungan dan hubungan yang baik antar karyawan mampu membentuk komitmen organisasi terlebih pada komitmen organisasi afeksi telah terpenuhi.

\section{PENUTUP}

Simpulan yang dapat ditarik dalam penelitian ini adalah variabel workplace relationship tidak berpengaruh terhadap intention to leave karyawan. Hal ini menunjukkan bahwa keinginan karyawan untuk keluar dari pekerjaan tidak serta merta dipengaruhi oleh hubungan kerja antar karyawan; Variabel job satisfaction berpengaruh terhadap intention to leave karyawan. Hal ini menunjukkan bahwa kepuasan kerja sangat penting bagi karyawan dalam menentukan pilihan apakah akan tetap bertahan dalam pekerjaannya atau keluar dari pekerjaannya. Ketika karyawan merasa puas akan pekerjaannya, keinginan untuk keluar pasti akan tidak ada.

Variabel affection organizational commiment berpengaruh terhadap intention to leave karyawan. Hal ini menunjukkan bahwa komitmen organisasi afektif berpengaruh terhadap keinginan karyawan untuk keluar atau berhenti dari pekerjaannya. Keadilan di tempat kerja dan keadilan antar karyawan dalam satu perusahaan menjadi sebuah faktor yang penting bagi karyawan untuk bertahan; Variabel co-worker trust berpengaruh terhadap Affective Organizational Commitment. Hal ini 
menunjukkan bahwa kepercayaan antar karyawan berpengaruh terhadap terciptanya komitmen organisasi afektif. Pada penelitian ini, responden melakukan self-report sehingga berpotensi menimbulkan common method bias.

Pada penelitian berikutnya, dapat dilakukan berbagai cara untuk mengawasi common method bias seperti dengan langkah perbaikan prosedural maupun perbaikan statistikal. Pengumpulan data pada riset ini hanya dilakukan dengan penyebaran kuesioner. Eksplorasi informasi responden menjadi sangat terbatas karena tidak mampu mencari keterangan lebih lanjut terhadap responden. Untuk menambahkan kekayaan informasi dan tambahan pengetahuan pada saat penyusunan hasil riset, penelitian selanjutnya dapat diperkaya dengan hasil wawancara. Berdasarkan hasil uji menggunakan WarpPLS 6.0 yang menunjukkan hasil tidak terdukung pada workplace relationship pada intention to leave karyawan, penelitian selanjutnya dapat mengeksplorasi efek interaksi, baik melalui mediasi maupun moderasi agar dapat berkembang dan menguji variabel-variabel lain yang mungkin dapat berinteraksi dengan variabel-variabel dalam penelitian ini.

\section{REFERENSI}

Alam, M. M., dan Mohammad, F. J. (2010). "Level of Job Satisfaction dan Intent to Leave Among Malaysian Nurses". Business Intelligence Journal Vol. 3 No. 1

Albdour, A. A., dan Altarawneh, I. I. (2014). "Employee Engagement dan Organizational Commitment: Evidence from Jordan”. International Journal of Business Vol. 19

Aziri, Brikend. (2011). "Job Satisfaction: A Literature Review". Management Research dan Practice Vol. 3 Issue 4

Balkan, M. O., Serin, A. E., dan Soran, S. (2014). "The Relationship Between Trust, Turnover Intentions and Emotions: An Application". European Scientific Journal. Vol 10, No. 2

Basak, E., Ekmekci, E., Bayram, Y., dan Bas, Y. (2013). "Analysis of Factors That Affect the Intention to Leave of White-collar Employees in Turkey Using Structural Equation Modelling". World Congress on Engineering dan Computer Science Vol. II

Chin,W.W. \& Newsted, P. R. (1999). 'Structural Equation Modeling Analysis with Small Samples using Partial Least Squares'. In R. H. Hoyle (ed.) Statistical strategies for small sample research. Thousand Oak: Sage Publication

Cho, J. Y., dan Park, H. (2011). "Exploring The Relationships Among Trust, Employee Satisfaction, Dan Organizational Commitment". Public Management Review Vol. 13

Colbert, A. E., Bono, J. E., dan Purvanova, R. K. (2016). "Flourishing Via Workplace Relationship: Moving Beyond Instrumental Support". Academy of Management Journal Vol. 59 No.4

Cook, J., \& Wall, T. (1980). New Work Attitude Measures of Trust, Orga-Nizational Commitment and Personal Need Non-Fulfilment. Journal of Occupational Psychology, 53(1): 39-52.

Cross, D. (1973), "The Worker Opinion Survey: a measure of shop floor satisfaction", Journal of Occupational Psychology, Vol. 47 No. 3/4

Eslami, Javad., dan Gharakhani, Davood. (2012). "Organizational Commitment dan Job Satisfaction". ARPN Journal of Science dan Technology Vol. 2 No. 2

Florida, R., dan Goodnight, J. (2005). "Managing for Creativity". Harvard Business Review.

Green, Kelli., Lopez, Mayra., Wyocksi, Allen., Kepner, Karl., Farsnworth, Derek., dan Clark, Jennifer. (2015). "Diversity in the Workplace: Benefits, Challenges, dan the Required Managerial Tools". IFAS Extension University of Florida

Hackman, R. J. (2009). "Why Teams Dont Work". Harvard Business Review Notice

Hair, et. al., Multivariate Data Analysis, Fifth Edition, Prentice Hall, Upper Saddle River: New Jersey

Hayes, Jeff. (2008). "Workplace Conflict dan How Business Can Harness It To Thrive". CPP Global Human Capital Report

Heathfield, S. M. (2015). “Top 10 Reasons Why Employees Quit Their Job. A Checklist for Talent 
Retention". http://humanresources.about.com/od/resigning-from-your-job/a/top-10-reasonsemployees-quit-their-job.htm, diakses pada tanggal 01 Maret 2017

Issa, D. A. R. M., Ahmad, Fais., dan Gelaidan, H. M. (2013). “Job Satisfaction dan Turnover Intention Based on Sales Person Stdanpoint”. Middle-East Journal of Scientific Research 14

Jafri, Hassan. (2016). "Impact of Employee Trust on Organizational Commitment dan Innovative Behavior of Employees: An Empirical Study on Public Sector Employees in Bhutan”. Royal University of Bhutan

Kim, S., dan Lee. H. (2006). "The Impact of Organizational Context dan Information Technology on Employee Knowledge-Sharing Capabilities”. Public Administration Review Volume 66 Issue 3 Lather, A. S., dan Singh, Archana. (2015). "A Study of the Impact of Workplace Relationship on Turnover Intentions". The International Journal of Business dan Management

Mahdi, A. F., Zin, M. Z. Z., Nor, M. R. M., Sakat, A. A., dan Naim, A. S. A. (2012). "The Relationship Between Job Satisfaction and Turnover Intention". American Journal of Applied Sciences 9

Mathieu, J. E., dan Zajac, D. M. (1990). "A Review dan Meta-Analysis of the Antecedents, Correlates, dan Consequences of Organizational Commitment". Psychological Bulletin Vol. 108

Mbah, S. E., dan Ikemefuna, C. O. (2012). "Job Satisfaction dan Employees Turnover Intentions in Total Nigeria plc. in Lagos State". International Journal of Humanities dan Social Science Vol. 2 No. 14

McAllister, D. J. (1995). "Affect dan Cognition Based Trust as Foundation for Interpersonal Cooperation in Organizations". Academy of Management Journal Vol. 38. No. 1

Mishra, P. K. (2013). "Job Satisfaction”. IOSR Journal of Humanities Dan Social Science Vol. 14 Issue 5

Mete, E. S., dan Sokmen, A. (2016). "The Influence of Workplace Bullying on Employee's Job Performance, Job Satisfaction dan Turnover Intention in a Newly Established Private Hospital”. International Review of Management dan Business Research Vol. 5 Issue 1

Mowday, R. T., Steers, R. M., dan Porter, L. W. (1979). "The Measurement of organizational commitment.". Journal of Vocational Behavior. Vol. 14, Issue 2

Ongori, Henry. (2007). "A Review of the Literature on Employee Turnover". African Journal of Business Management pp. 049-054

Porter, L.W., Steers, R.M., Mowday, R.T. dan Boulian, P.V. (1974). 'Organizational Commitment, Job Satisfaction, and Turnover Among Psychiatric Technicians'. Journal of Applied Psychology, 59: 603 - 609.

Purnadi, Pungki. (2019). “Talent Management Modul”. Pungki Purnadi Associate Jakarta

Rigoni. (2016). "Do Employees Really Know What's Expected of Them". https://www.gallup.com/businessjournal/195803/employees-really-know-expected.aspx diakses tanggal 1 Maret 2017.

Rizwan, M., Arshad, Q. M., Munir, H. M. A., Iqbal, F., dan Hussain, A. (2014). "Determinants of Employee intention to leave: A Study from Pakistan". International Jurnal of Human Resource Studies Vol. 4 No. 3

Rotenberry, P.F., \& Moberg, P.J. (2007). "Assessing the impact of job involvement on performance." Management Research News, 30, 203-215 Psychology, 63, 53-61

Rusbult, C. E. and Farrel, D. (1983). A Longitudinal Test of The Investment Model: Impact on Job Satisfaction, Job Commitment, and Turnover Variation in Rewards, Costs, Alternatives, and Investments'. Journal of Applied Psychology, 68(3): 429-438.

Seashore, S. E., dan Taber, T. D., (1975). "Job Satisfaction Indicators dan Their Correlates". University of Michigan 
Sholihin, Mahfud., \& Pike, R. (2009). Fairness in Performance Evaluation and Its Behavioural Consequences. Accounting and Business Research, 39(4): 397-413

Tan, H. H., dan Lim, A. K. H. (2010). "Trust in Coworkers dan Trust in Organizations". The Journal of Psychology: Interdisciplinary dan Applied

Tamer, Idiil., dan Dereli, Beliz. (2014). "The Relationship Between Interpersonal Trust, Peer Support dan Organizational Commitment". Marmara Universitesi Oneri Dergisi

Williams, Tiara. (2015). "The psychology of interpersonal trust How People feel when it comes to trusting someone". Mc Kendree University

Yasmin, K., dan Marzuki, N. A. (2015). "Impact Organizational Commitment on Intention to Quit Among Psychaitric Nurses: Evidence from Pakistan”. International Journal of Learning dan Development Vol. 5 No. 4 